\title{
Blood concentrations of gonadotrophins, prolactin and gonadal steroids in males and in non-pregnant and pregnant female African elephants (Loxodonta africana)
}

\author{
A. S. McNeilly, R. D. Martin* $\ddagger$ J. K. Hodges* and G. L. Smuts $\dagger$
}

M.R.C. Unit of Reproductive Biology, University of Edinburgh Centre for Reproductive Biology, 37 Chalmers Street, Edinburgh EH3 9EW, U.K.; * Institute of Zoology, Regent's Park, London NWI 4RY, U.K.; and †Natal Parks Board, P.O. Box 662, Pietermaritzburg 3200, South Africa

\begin{abstract}
Summary. No seasonal variation in any of the hormones measured was apparent in males or females. Testosterone levels in males increased around puberty (10-11 years) and remained significantly higher in adult than prepubertal males. This was not accompanied by any significant change in levels of LH, FSH or prolactin.

In non-pregnant females there was no apparent difference in levels of LH, FSH or prolactin with age. There was a significant increase in progesterone around puberty (12 years) but there was considerable overlap in values between prepubertal and adult females.

During pregnancy, progesterone levels were significantly higher than in nonpregnant females with maximum levels occurring at mid-pregnancy (9-12 months). However, there was considerable overlap in values between non-pregnancy and pregnancy. Concentrations of LH and FSH decreased significantly during midpregnancy while prolactin levels increased dramatically during pregnancy; after 7 months of gestation until term levels were always at least $8 \mathrm{ng} / \mathrm{ml}$ greater than in any non-pregnant female. It is suggested that this consistent increase in plasma/serum levels of prolactin can be used to diagnose pregnancy in the elephant.
\end{abstract}

\section{Introduction}

Very little is known about the reproductive endocrinology of the African elephant (Loxodonta africana), but such information is essential to develop controlled breeding programmes in captivity. In view of the long gestation period of the elephant (approximately 22 months) a reliable method for the diagnosis of pregnancy is also important.

Luteinizing hormone ( $\mathrm{LH}$ ) and follicle-stimulating hormone (FSH) have been identified, by biological and immunological assays, in pituitary glands from African elephants (Carr, 1969). Plasma levels of LH increased around oestrus and after the injection of LH-RH in two female Asiatic elephants (Chappel \& Schmidt, 1979) and gonadotrophin-like activity has also been measured in the urine of a pregnant Asiatic elephant (Fujimoto, Koto, Imori \& Nakama, 1970).

Plasma levels of unconjugated oestrogens and progesterone (Plotka, Seal, Schobert \& Schmoller, 1975) and urinary levels of oestrone and oestradiol (Ramsay, Lasley \& Stabenfeldt, 1981) are low in female elephants in comparison with most other species. The corpora lutea have a

‡ Present address: Department of Anthropology, University College, Gower Street, London WCl, U.K. 
low content of and secretory capacity for progesterone (Smith, Hanks \& Short, 1969; Ogle, Braach \& Buss, 1973) and although a modest increase in plasma concentrations of progesterone may occur during pregnancy (Plotka et al., 1975) this needs to be confirmed. Circulating levels of testosterone in male Indian elephants are generally low, but increase dramatically during the period of increased aggressive and sexual behaviour associated with the phenomenon known as 'musth' (Jainudeen, Katongole \& Short, 1972). 'Musth' has only recently been recognized in African elephants (Poole \& Moss, 1981) and although testicular testosterone levels are extremely variable (Buss \& Johnson, 1967; Short, Mann \& Hay, 1967) no data are available on plasma testosterone values in male African elephants.

Likewise, there is no information on changes in plasma levels of LH in the male or on FSH or prolactin in the male or the female. With the development of heterologous radioimmunoassays for LH, FSH and prolactin and steroid radioimmunoassays of improved sensitivity and specificity, we have examined the changes in blood concentrations of these hormones in male and female African elephants of different ages and reproductive status.

\section{Materials and Methods}

Animals and blood samples. Blood samples kindly made available by Dr R. C. Malpas (Department of Applied Biology, University of Cambridge, U.K.) were obtained from 27 male and 90 female (55 non-pregnant; 35 pregnant) elephants shot between September 1973 and April 1974 in the Rwenzori National Park and in the Kabalega Falls National Park both north (Kabalega North) and south (Kabalega South) of the river Nile in Uganda. The period of collection covered the wet and dry seasons in all three areas (Malpas, 1977). A further series of blood samples was obtained from 2 male and 39 females ( 8 non-pregnant; 31 pregnant) elephants shot between August 1977 and April 1978 in the Central District of Kruger National Park, South Africa. After collection of blood samples, serum (Uganda collections) or plasma (South African collections) was separated, frozen as soon as possible $(1-6 \mathrm{~h})$ and stored at $-20^{\circ} \mathrm{C}$ until hormonal analysis at the M.R.C. Unit of Reproductive Biology, Edinburgh.

The age of the animals was estimated by the criteria of Laws (1966). All female elephants of reproductive age ( $>10$ years old) were examined for evidence of pregnancy and/or lactation. Stage of pregnancy was determined by reference to fetal weight and crown-rump length (Perry, 1953; Laws, 1966). In some instances the ovaries were examined and the number and state of any corpora lutea recorded.

\section{Radioimmunoassays of $\mathrm{LH}, \mathrm{FSH}$ and prolactin}

LH, FSH and prolactin concentrations were measured by the heterologous radioimmunoassays described in detail previously (LH: Welschen et al., 1975; FSH: McNeilly, McNeilly, Walton \& Cunningham, 1976; prolactin: McNeilly \& Friesen, 1978). Reagents, buffers, volumes and times of incubation were exactly as described.

Specificity. Since no purified preparations of elephant LH, FSH or prolactin were available a crude pituitary extract was prepared from acetone-dried pituitary glands collected from African elephants and kindly provided by Mr W. R. Carr, Animal Breeding Research Organization, Roslin, Midlothian (Carr, 1969). Approximately $100 \mathrm{mg}$ amounts $(\mathrm{n}=4)$ of this powder were extracted in $4 \mathrm{ml} 0.01 \mathrm{~N}$-ammonium bicarbonate, $\mathrm{pH} \mathrm{9.0.} \mathrm{After} \mathrm{shaking} \mathrm{for} 2 \mathrm{~h}$ at room temperature the extract was centrifuged at $600 \mathrm{~g}$ for $1 \mathrm{~h}$ at $4^{\circ} \mathrm{C}$ and the supernatant stored at $-20^{\circ} \mathrm{C}$ until assayed.

Parallelism between the ovine hormone standards used and dilutions of the elephant pituitary extract and plasma and serum samples from male and female elephants was then assessed. The slopes of the dose-response curves were not significantly different in each of the radioimmuno- 
assays for $\mathrm{LH}, \mathrm{FSH}$ and prolactin. Therefore all samples were assayed against, and are reported in terms of, ng of the appropriate ovine pituitary standard (NIH-LH-S14, NIH-FSH-S10 and NIH-PS6).

Since there was no effect of plasma or serum in these assays, the hormone measurements in each fluid were taken as comparable and results are expressed in terms of plasma/serum.

Accuracy and precision. Accuracy of the assays assessed by measurement of known amounts of ovine standard or diluted elephant pituitary extract added to elephant plasma and serum was $95 \pm$ 3 (s.e.m.), $102 \pm 4$ and $98 \pm 4 \%$ for LH, FSH and prolactin respectively $(n=7)$. The precision, expressed as the intra- and inter-assay coefficients of variation (\%) assessed by repeated assays of 3 pools of elephant plasma with binding in the 3 assays over the range $32-83 \% \mathrm{~B} / \mathrm{Bo}$, were 10 and $14 \%$ $(n=13)$ respectively for $\mathrm{LH}, 9$ and $12 \%$ for FSH and 8 and $13 \%$ for prolactin.

Identification of hormones measured. To assess the form of the immunologically active elephant hormone measured by each radioimmunoassay, elephant pituitary extract was fractionated at $4^{\circ} \mathrm{C}$ by gel filtration on Sephadex G-100 $(2 \times 50 \mathrm{~cm})$, eluted with $0.25 \mathrm{M}$-Tris- $\mathrm{HCl}(\mathrm{pH} \mathrm{7.6)}$ containing $0.1 \%$ bovine serum albumin (BSA). Fractions $(1 \mathrm{ml})$ were collected and analysed for LH, FSH and prolactin by radioimmunoassay and by radioreceptor assay (LH: Cheng, 1976; FSH: Cheng, 1975; prolactin: Shiu, Kelly \& Friesen, 1973).

After gel filtration of elephant pituitary extract, single peaks of radioimmunoassayable $\mathrm{LH}$, FSH and prolactin were found eluting in positions similar to those for the comparable ovine ${ }^{125}$ Ilabelled hormones. For each hormone the fractions containing immunoreactivity corresponded with those displaying radioreceptor activity. Because there was no suitable elephant pituitary standard it was not possible to make a quantitative comparison of the radioimmuno- and radioreceptor assay estimates of activity.

\section{Radioimmunoassay of steroids}

Plasma or serum levels of testosterone and progesterene were measured by the specific radioimmunoassays described by Corker \& Davidson (1978) and Scaramuzzi, Corker, Young \& Baird (1975) respectively. All samples were measured in duplicate. Procedural losses during extraction were monitored individually by the addition of tracer amounts of $\left[{ }^{3} \mathrm{H}\right]$ testosterone or $\left[{ }^{3} \mathrm{H}\right]$ progesterone (sp. act. $60 \mathrm{Ci} / \mathrm{mmol}$ and $90 \mathrm{Ci} / \mathrm{mmol}$, respectively). Mean recovery values were $82 \pm$ $3 \%$ for testosterone $(n=29)$ and $85 \pm 4 \%$ for progesterone $(n=20)$ and results were corrected accordingly. The accuracy of each assay, assessed by recovery of known amounts of pure unlabelled testosterone or progesterone (100-10000 pg) added to plasma or serum samples from various elephants, was $96 \pm 3 \%(n=20)$ and $97 \pm 5 \%(n=20)$ respectively. The sensitivity and intra- and interassay precision (as coefficient of variation) were $10 \mathrm{pg} / \mathrm{ml}, 10.4 \%$ and $11.0 \%$ for testosterone and $50 \mathrm{pg} / \mathrm{ml}, 9 \cdot 3 \%$ and $12.6 \%$ for progesterone.

In addition, progesterone concentrations (range $375-3738 \mathrm{pg} / \mathrm{ml}$ ) in plasma samples from 2 non-pregnant and 4 pregnant elephants were measured before and after celite chromatography (Hodges, Gulick, Czekala \& Lasley, 1981) using a different specific progesterone radioimmunoassay (Hodges, Eastman \& Jenkins, 1982). The results obtained by the three different procedures were not significantly different $(P>0.05$, paired $t$ test).

Statistical analysis was by one- or two-way analysis of variation and by Student's $t$ test.

\section{Results}

\section{Hormone levels in male elephants}

Plasma/serum samples were obtained from a total of 29 male elephants aged between 1 and 30 years of age. No significant changes associated with age were seen in concentrations of LH (overall mean \pm s.e.m.: $15 \pm 4 \mathrm{ng} / \mathrm{ml}$; range $8-23 \mathrm{ng} / \mathrm{ml})$, FSH $(72 \pm 8 \mathrm{ng} / \mathrm{ml}$; range $10-194 \mathrm{ng} / \mathrm{ml})$, pro- 
lactin $(0.9 \pm 0 \cdot 1 \mathrm{ng} / \mathrm{ml} ;$ range $0 \cdot 2-3 \cdot 7 \mathrm{ng} / \mathrm{ml})$ and progesterone $(604 \pm 118 \mathrm{pg} / \mathrm{ml} ;$ range $177-3125$ $\mathrm{pg} / \mathrm{ml})$. In contrast, there was a significant difference $(P<0.01)$ between testosterone values in animals less than $(0.43 \pm 0.09 \mathrm{ng} / \mathrm{ml}, \mathrm{N}=10)$ or greater than $(2.57 \pm 0.52 \mathrm{ng} / \mathrm{ml}, \mathrm{N}=17) 12$ years of age, the time at which sexual maturity is first recognized (Perry, 1953). None of the animals in the younger group had levels $>1 \mathrm{ng} / \mathrm{ml}$ (range $0 \cdot 14-0.98 \mathrm{ng} / \mathrm{ml}$ ) whereas 12 of the 17 animals in the older group had levels exceeding this value $(1 \cdot 13-6.5 \mathrm{ng} / \mathrm{ml})$.

\section{Hormone levels in non-pregnant female elephants}

Blood samples were obtained from 63 non-pregnant females 1-60 years of age. There was no significant change associated with age for mean \pm s.e.m. concentrations of $\mathrm{LH}(22 \pm 1.4 \mathrm{ng} / \mathrm{ml}$, range $8-52 \mathrm{ng} / \mathrm{ml})$, FSH $(95 \pm 9 \mathrm{ng} / \mathrm{ml}$; range $30-256 \mathrm{ng} / \mathrm{ml})$ or prolactin $(6.9 \pm 0.7$; range $0.8-22.4$ $\mathrm{ng} / \mathrm{ml})$. However, progesterone values in 15 females $<13$ years of age $(316 \pm 52 \mathrm{pg} / \mathrm{ml}$; range 120 $595 \mathrm{pg} / \mathrm{ml})$ were significantly lower $(P<0.01)$ than in the older females $(707 \pm 77 \mathrm{pg} / \mathrm{ml}$; range $92-$ $1495 \mathrm{pg} / \mathrm{ml}, \mathrm{N}=48$ ) although there was considerable overlap between the two groups (Text-fig. 1 ).

\section{Hormone levels in pregnant female elephants}

Blood samples were obtained from 66 pregnant animals $13-49$ years old of which $49(74 \%)$ were lactating. Of the 37 females that were $>13$ months pregnant, only 2 were not lactating.

$L H$ and $F S H$. The levels of LH and FSH in plasma/serum throughout pregnancy are shown in Text-fig. 2. For statistical analysis, levels were grouped at 4 monthly intervals, i.e. 1-4, 5-8, 9-12 months etc. Plasma/serum levels of LH tended to be lower throughout pregnancy than those in non-

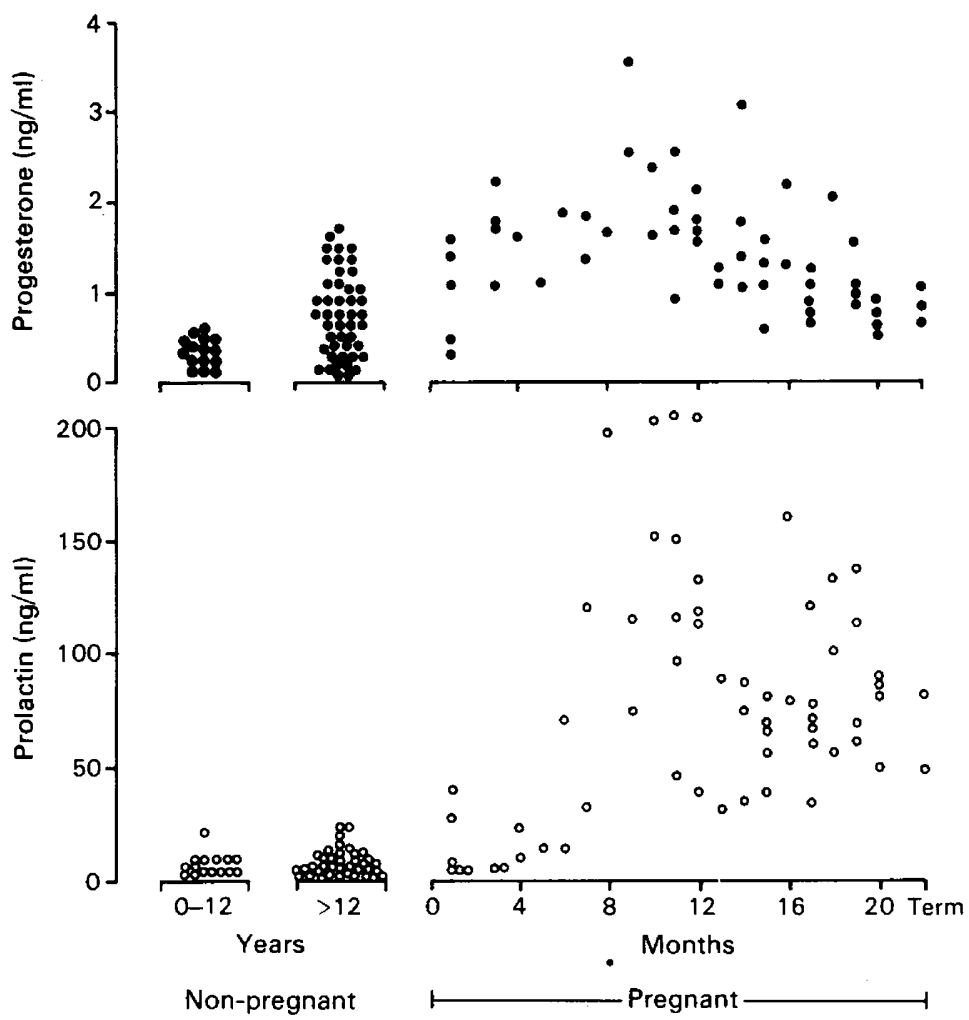

Text-fig. 1. Blood concentrations of progesterone and prolactin in female African elephants at different ages and stages of pregnancy. 


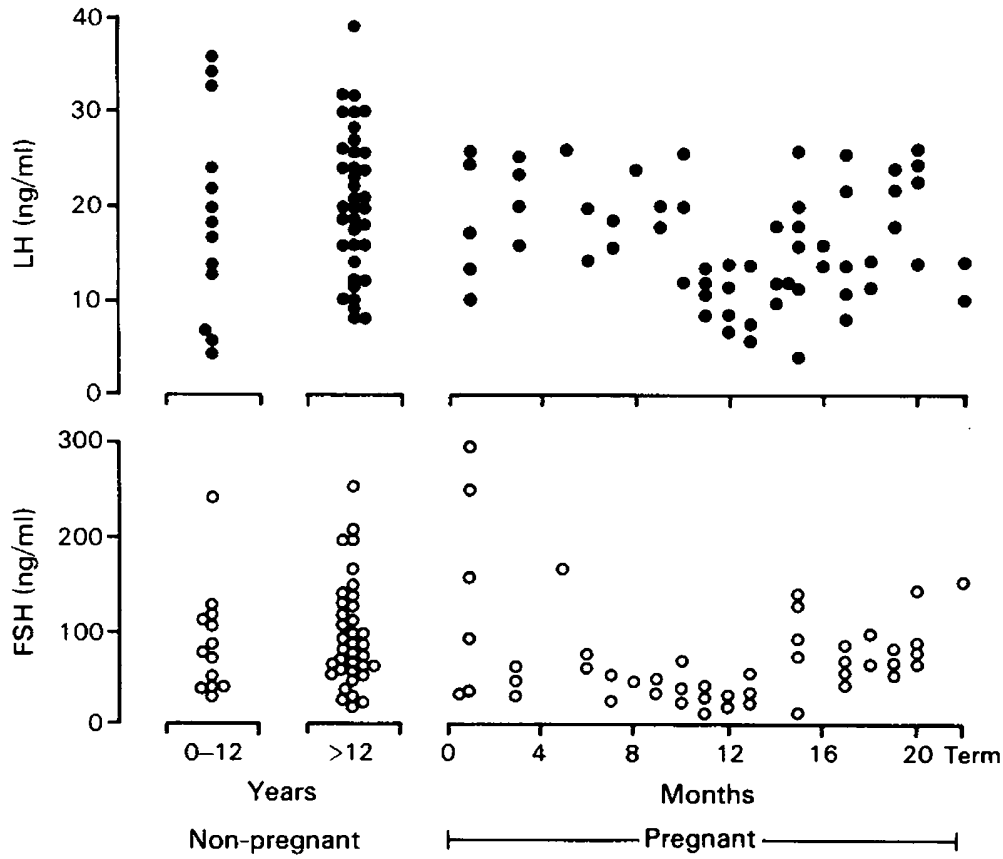

Text-fig. 2. Blood concentrations of LH (O) and FSH (O) in female African elephants at different ages and stages of pregnancy.

pregnant females but this was only significant $(P<0.05)$ between 9 and 16 months of pregnancy (Text-fig. 2). After an initial non-significant increase during the first 2 months of pregnancy, FSH values were lower than in non-pregnant animals throughout the rest of gestation, although this was only significant $(P<0.05)$ between 9 and 12 months of gestation (Text-fig. 2$)$.

Progesterone. Progesterone concentrations during pregnancy $(1414 \pm 92 \mathrm{pg} / \mathrm{ml} ; \mathrm{N}=53)$ were significantly higher $(P<0.01)$ than those in mature $(>12$ years $)$ non-pregnant females

Table 1. Plasma concentrations of progesterone in individual female African elephants in relation to the number and physiological state of the corpora lutea (CL) or corpora albicantia (CA) in both ovaries of elephants shot in the Central District of the Kruger National Park, South Africa in August 1977

\begin{tabular}{lccccc}
\hline $\begin{array}{c}\text { Reproductive } \\
\text { status }\end{array}$ & $\begin{array}{c}\text { Animal } \\
\text { no. }\end{array}$ & $\begin{array}{c}\text { Age } \\
\text { (years) }\end{array}$ & $\begin{array}{c}\text { CL or } \\
\text { CA }\end{array}$ & No. & $\begin{array}{c}\text { Plasma } \\
\text { progesterone } \\
\text { (pg/ml) }\end{array}$ \\
\hline Anoestrous & 1341 & 38 & CA & Numerous & 242 \\
& 1348 & 14 & CA & Numerous & 310 \\
& 1340 & 26 & CA & Numerous & 365 \\
Oestrous & 1349 & 21 & CL & 1 & 747 \\
& 1359 & 20 & CL & 2 & 684 \\
& 1358 & 14 & CL & 3 & 1300 \\
Pregnant & 1353 & 16 & CL & 6 & 1065 \\
& 1350 & 15 & CL & 12 & 1762 \\
& 1352 & 14 & CL & 14 & 1832 \\
& 1355 & 20 & CL & 13 & 800 \\
& 1354 & 30 & CL & 12 & 522 \\
\hline
\end{tabular}


$(707 \pm 77 \mathrm{pg} / \mathrm{ml}, \mathrm{N}=48$ ). However, there was considerable overlap between values in the two groups. The highest levels of progesterone occurred during mid-pregnancy and levels declined towards term (Text-fig. 1). From 8 months of gestation until term only 10 of the 44 progesterone values were above the maximum level seen in non-pregnant females (Text-fig. 1).

In 7 non-pregnant and 4 pregnant elephants the ovaries were examined and the number and appearance of the corpora lutea were recorded. An increase in the number of corpora lutea was associated with increased plasma levels of progesterone except for values for 2 pregnant elephants at 19 and 20 months gestation which were low (Table 1).

Prolactin. There was a significant increase $(P<0.001)$ in prolactin values during pregnancy $(50 \pm 7 \mathrm{ng} / \mathrm{ml}, \mathrm{N}=63)$ compared with those in non-pregnant females $(6.9 \pm 0.7 \mathrm{ng} / \mathrm{ml} ; \mathrm{N}=61)$ (Text-fig. 1). After 7 months of pregnancy all prolactin concentrations were at least $8 \mathrm{ng} / \mathrm{ml}$ greater than the maximum level found in any non-pregnant female (Text-fig. 1). There was no significant difference in prolactin values between lactating and non-lactating pregnant animals.

\section{Discussion}

The data presented in this paper examine for the first time in some detail the changes in reproductive hormones in male and female African elephants in relation to age and pregnancy.

The heterologous radioimmunoassays for $\mathrm{LH}, \mathrm{FSH}$ and prolactin have been validated for several different species and have always been shown to be specific (LH: Welschen et al., 1975; Hodges, 1978; FSH: McNeilly et al., 1976; Bass, McNeilly \& Moreton, 1979; Fraser, 1981; prolactin; McNeilly \& Friesen, 1978; McNeilly, Abbott, Lunn, Chambers \& Hearn, 1981; Hinds \& Tyndale-Biscoe, 1982). In the absence of purified elephant pituitary hormones, validation for each hormone radioimmunoassay was confirmed by the parallelism between standard hormone preparations, plasma and serum samples and dilutions of elephant pituitary extract. Recovery of added hormone to elephant plasma or serum samples showed that the radioimmunoassays were applicable in quantitative terms and the activity measured in each appeared as single separate peaks on Sephadex gel filtration. In the circumstances it is felt that each of these hormone assays has been validated for use in the elephant, although final confirmation must await the availability of purified preparations of elephant LH, FSH and prolactin.

The failure to detect any differences between LH, FSH and prolactin levels in male or nonpregnant females at any stage in samples collected in Uganda and South Africa and at different times of the year (between August and A pril) suggests that any seasonal change in the levels of these hormones is likely to be small. However, a decrease in thyroxine and triiodothyronine uptake values was found in the dry compared to wet seasons in elephants in the Kabalega National Park, Uganda (Brown, White \& Malpas, 1978). The lack of differences between pre- and post-pubertal animals is probably due to the relatively small number of samples collected around this time.

The similarity of prolactin values in lactating and non-lactating females is not too surprising because it was not possible to record when last suckling occurred and the age of calf was not recorded. Since both suckling and time post partum are the most important contributors to the levels of prolactin post partum in mammals that have been adequately studied (Cowie, Forsyth \& Hart, 1980 ), the role of prolactin in lactation in the elephant clearly needs more detailed investigation.

The increase in testosterone levels after 11 years of age in male elephants coincides with the onset of puberty (Perry, 1953). The levels are similar to those reported for male Asian elephants but no values as high as those observed during the musth in male Asian elephants (Jainudeen et al., 1972) were obtained.

In the female there was a clear increase in progesterone values after puberty ( $>10$ years of age; Perry, 1953) although there was considerable overlap in levels between prepubertal and mature females. The levels agree with those reported by Plotka et al. (1975) but are higher than those suggested originally by Hanks \& Short (1972). The higher than expected levels of progesterone in prepubertal animals may have been due to an unidentified progestagen cross-reacting in the radio- 
immunoassay used, but the progesterone values were confirmed by using a different radioimmunoassay for progesterone with and without celite chromatography. As in the hyrax, the low levels of progesterone during pregnancy in the elephant may be due to rapid conversion of progesterone to $20 \alpha$-dihydroprogesterone by erythrocytes (Heap, Gombe \& Sale, 1975). However, metabolism of progesterone in fresh samples of blood in the elephant was less than $2 \%$ after a 1-h incubation period (A. J. Hill \& J. K. Hodges, unpublished observations). In addition, elephant serum levels of $20 \alpha$ - and $17 \alpha$-dihydroprogesterone, the main products of erythrocyte metabolism, are similar to those of progesterone (J. K. Hodges, unpublished observations).

There appeared to be an increase in progesterone concentrations in relation to an increase in the number of corpora lutea present in the ovaries. This is of interest since it has been suggested that, because of the small capacity of individual corpora lutea to secrete progesterone, a certain critical mass of luteal tissue may be required to maintain plasma levels of progesterone at a level compatible with pregnancy (Perry, 1953; Hanks \& Short, 1972) although this view has been questioned (Ogle et al., 1973; Smith \& Buss, 1975). During pregnancy plasma levels were significantly higher than in non pregnant females. However, there was considerable overlap in levels of progesterone, indicating that measurement of progesterone alone would not be suitable to diagnose pregnancy in the elephant. In the second half of pregnancy, there was a decline in progesterone values towards term, when there is histological evidence of a reduction in corpus luteum function (Smith \& Buss, 1975).

The decline in plasma levels of LH and FSH between 10 and 14 months of pregnancy occurs when there is also a repression of follicular development (Smith \& Buss, 1975), probably due to the negative feedback effects of gonadal and placental steroids.

The dramatic increase in prolactin values during pregnancy could be used for pregnancy diagnosis in the elephant. The reason for the increase in the elephant is not known, but in other species such an increase occurs in relation to the raised circulating oestrogen values associated with pregnancy (McNeilly, 1980; Cowie et al., 1980). Since a similar rise and change in ratio of oestrogens also occurs during pregnancy in the elephant, and coincides with the time when prolactin levels are also increased (Hodges, Henderson \& McNeilly, 1983) it is possible that, as in other species, oestrogens in the elephant act directly to increase prolactin secretion. It is also possible that the prolactin is placental in origin although placental lactogens from other species do not cross-react in the radioimmunoassay used in the present study (McNeilly \& Friesen, 1978).

While no relationship between lactation and prolactin was apparent in non-pregnant females, when prolactin levels were high in the second half of pregnancy almost all elephants were lactating as judged by the presence of milk in the mammary gland. Perry (1953) also found that in a majority of animals pregnancy was accompanied by lactation.

The present results indicate that measurement of plasma or serum levels of prolactin can be used to diagnose pregnancy at least beyond 7 months of gestation, a finding of considerable advantage to those interested in breeding programmes for the elephant.

We thank Professor W. R. Butt and Professor H. G. Friesen, Dr S. S. Lynch and Dr R. Welschen, and the NIH (Bethesda, Maryland, U.S.A.) for hormones and reagents used in radioimmunoassays; Miss B. Archibald, Mrs C. Henderson and Mr D. W. Davidson for skilled technical assistance; Mr W. Carr for supply of acetone-dried pituitary glands; Dr R. C. Malpas for the serum samples collected in Uganda; and the National Parks Board of South Africa for cooperation and help with the collection of samples.

\section{References}

Bass, J.J., McNeilly, A.S. \& Moreton, H.E. (1979) Plasma concentrations of FSH and $\mathrm{LH}$ in entire and castrated prepubertal bull calves treated with GnRH. J. Reprod. Fert. 57, 219-222.
Brown, I.R.F., White, P.T. \& Malpas, R.C. (1978) Proteins and other nitrogenous constituents in the blood serum of the African elephant, Loxodonta africana. Comp. Biochem. Physiol. 59A, 267-270. 
Buss, I.O. \& Johnson, O.W. (1967) Relationship of Leydig cell characteristics and intratesticular testosterone levels to sexual activity in the African elephant. Anat. Rec. 157, 191-196.

Carr, W.R. (1969) Studies on the pituitary gonadotrophins of the African elephant. J. Reprod. Fert., Suppl. 6, 219-223.

Chappel, S.C. \& Schmidt, M. (1979) Cyclic release of luteinizing hormone and the effects of luteinizing hormone-releasing hormone injection in Asiatic elephants. Am. J. vet. Res, 40, 451-453.

Cheng, K.W. (1975) A radioreceptor assay for follicle stimulating hormone. J. clin. Endocr. Metab. 41, 581589.

Cheng, K.W. (1976) Carbomethylation of methionine residues in bovine pituitary luteinizing hormone and its subunits. Biochem. J. 159, 71-77.

Corker, C.S. \& Davidson, D. (1978) A radioimmunoassay of testosterone in various biological fluids without chromatography. J. Steroid Biochem. 19, 373-374.

Cowie, A.T., Forsyth, I.A. \& Hart, I.C. (1980) Hormonal Control of Lactation. Springer Verlag, Berlin.

Fraser, H.M. (1981) Effect of oestrogen on gonadotrophin release in stumptailed monkeys (Macaca arctoides) treated chronically with an agonist analogue of luteinizing hormone releasing hormone. $J$. Endocr. 91, 525-530.

Fujimoto, E., Koto, N., Imori, T. \& Nakama, S. (1970) Gonadotrophin in the urine of a pregnant Indian elephant-a case report. Zoologica 55, 73-80.

Hanks, J. \& Short, R.V. (1972) The formation and function of the corpus luteum in the African elephant, Loxodonta africana. J. Reprod. Fert. 29, 7989.

Heap, R.B., Gombe, S. \& Sale, J.B. (1975) Pregnancy in the hyrax and erythrocyte metabolism of progesterone. Nature, Lond. 257, 809-811.

Hinds, L.A. \& Tyndale-Biscoe, C.H. (1982) Prolactin in the marsupial Macropus eugenii, during the estrous cycle, pregnancy and lactation. Biol. Reprod. (in press).

Hodges, J.K. (1978) Effects of gonadectomy and oestradiol treatment on plasma luteinizing hormone concentrations in the marmoset monkey. J. Endocr. 76, 271-281.

Hodges, J.K., Gulick, B.L., Czekala, N.M. \& Lasley, B.L. (1981) Comparison of urinary oestrogen excretion in South American primates. J. Reprod. Fert. 61, 83-90.

Hodges, J.K., Eastman, S.A.K. \& Jenkins, N. (1982) Sex steroids and their relationship to binding proteins in the serum of the marmoset monkey (Callithrix jacchus). $J$. Endocr. (in press).

Hodges, J.K., Henderson, C. \& McNeilly, A.S. (1983) Plasma concentrations of oestrogens during pregnancy in the African elephant (Loxodonta africana). J. Reprod. Fert. 67, 73-87.

Jainudeen, M.R., Katongole, C.B. \& Short, R.V. (1972) Plasma testosterone levels in relation to musth and sexual activity in the male Asiatic elephant, Elephas maximus. J. Reprod. Fert. 29, 99-103.
Laws, R.M. (1966) Age criteria for the African elephant. E. Afr. Wldl. J. 4, 1-37.

Malpas, R.C. (1977) Diet and the condition and growth of elephants in Uganda. $J$. appl. Ecol. 14, 489-504.

McNeilly, A.S. (1980) Prolactin and the control of gonadotrophin secretion in the female. J. Reprod. Fert. 58, 537-549.

McNeilly, A.S. \& Friesen, H.G. (1978) Heterologous radioimmunoassay for rabbit prolactin. Endocrinology 102, 1539-1547.

McNeilly, A.S., Abbott, D.H., Lunn, S.F., Chambers, P.C. \& Hearn, J.P. (1981) Plasma prolactin concentrations during the ovarian cycle and lactation and their relationship to return of fertility post partum in the common marmoset (Callithrix jacchus). J. Reprod. Fert. 62, 353-360.

McNeilly, J.R., McNeilly, A.S., Walton, J.S. \& Cunningham, F.J. (1976) Development and application of a heterologous radioimmunoassay for ovine folliclestimulating hormone. J. Endocr. 70, 69-79.

Ogle, T.F., Braach, H.H. \& Buss, I.O. (1973) Fine structure and progesterone concentration in the corpus luteum of the African elephant. Anat. Rec. 175, 707-724.

Perry, J.S. (1953) The reproduction of the African elephant, Loxodonta africana. Phil. Trans. R. Soc. B 237, 93-149.

Plotka, E.D., Seal, U.S., Schobert, E.E. \& Schmoller, G.C. (1975) Serum progesterone and estrogens in elephants. Endocrinology 97, 485-487.

Poole, J.H. \& Moss, C.J. (1981) Musth in the African elephant, Loxodonta africana. Nature, Lond. 292 , 830-831.

Ramsay, E.C., Lasley, B.L. \& Stabenfeldt, G.H. (1981) Monitoring the estrous cycle of the Asian elephant (Elaphus maximus) using urinary estrogens. Am. J. vet. Res. 42, 256-260.

Scaramuzzi, R.J., Corker, C.S., Young, G. \& Baird, D.T. (1975) Production of antisera to steroid hormones in sheep. In Steroid Immunoassay, pp. 111-122. Eds E. H. D. Cameron, S. G. Hillier \& K. Griffiths. Alpha Omega Alpha Publishing Co., Cardiff.

Shiu, R.P.C., Kelly, P.A. \& Friesen, H.G. (1973) Radioreceptor assay for prolactin and other lactogenic hormones. Science, N.Y. 180, 969-971.

Short, R.V., Mann, T. \& Hay, M.F. (1967) Male reproductive organs of the African elephant, Loxodonta africana. J. Reprod. Fert. 13, 516-536.

Smith, J.G., Hanks, J. \& Short, R.V. (1969) Biochemical observations on the corpora lutea of the African elephant, Loxodonta africana. J. Reprod. Fert. 20, 111-117.

Smith, N.S. \& Buss, I.O. (1975) Formation, function and persistence of the corpora lutea of the African elephant (Loxodonta africana). J. Mammal. 56, 30-43.

Welschen, R., Osman, P., Dullaart, J., de Greef, W.J., Uilenbroek, J. Th.J. \& de Jong, F.H. (1975) Levels of follicle-stimulating hormone, luteinizing hormone, oestradiol-17 $\beta$ and progesterone and follicular growth in the pseudopregnant rat. $J$. Endocr. 64, 37-47. 